\title{
A Systematic Review of the Influence of Internal Marketing on Service Innovation
}

\author{
Soheila Raeisi ${ }^{1, * \mathbb{D}}$, Nur Suhaili Ramli ${ }^{2}$ and Meng Lingjie ${ }^{1, *}$ \\ 1 Department of Economics and Management, Nanjing University of Science and Technology, \\ Nanjing 210094, China \\ 2 Department of Management, Ca' Foscari University of Venice, 30123 Venice, Italy; nursuhaili.ramli@unive.it \\ * Correspondence: 914107020147@njust.edu.cn (S.R.); menglj@njust.edu.cn (M.L.)
}

Received: 31 December 2019; Accepted: 23 February 2020; Published: 11 September 2020

\begin{abstract}
This paper aims aimed to present the trends of the literature review in internal marketing and service innovation between 1990 and 2016. The significant reason to conduct this research is that significant variables of internal marketing to link with service innovation are not clearly defined. This research yielded 22 systematic reviews of articles in the Scopus library and adopted a thematic analysis to analyze the data collected. This study provides provided answers to research questions by elaborating on overall trends, objectives, theoretical framework, methodologies, and potential variables that strongly connect between internal marketing and service innovation. While sample sizes are limited to this paper, it suggests suggested fruitful recommendations for future research to overcome this limitation. This research has had two practical implications for managers to redefine their roles and the relationship between members of the organization and to help managers and the firms to consider internal marketing efforts towards motivation, organizational culture, and organizational learning.
\end{abstract}

Keywords: internal marketing; service innovation; a systematic review; thematic analysis; human resources

\section{Introduction}

In the digital age, innovation in an organization is a process of renovation inside the company that aims to achieve the customers' satisfaction and fidelity, as well as ensure the survival and success rate. In this dynamic environment, companies require service innovation as a managerial response to create a competitive advantage. Besides, there is continuing interest among academics, practitioners, and policy-makers in methods to achieve accelerated innovation (Ellwood et al. 2017). Therefore, the way the firm uses its human resources and competencies, the ability to combine the resources, the methods, processes, and techniques to offer services, are essential in the innovation process (Afuah 2002).

In the service innovation context, there is not a single "best way" to characterize how service innovations are created. Some early studies illustrate with evidence that service innovation processes are multiform (Toivonen et al. 2006). In contrast, many organizations show that the innovation process is still deeply rooted in a non-digital past (Troilo et al. 2017). Due to this aspect of service innovation, scholars suggest that the development of new services takes place as a response to a particular situation and is built and implemented naturally around specific individuals or teams (Bernstein 2005; Kale 2007). The example from studies between 2006 and 2017 demonstrates an interesting debate in the area. Thus, we built our study from these studies to reach the research goal to draw trends over time in marketing and service innovation. 
The activities related to service innovation are integrated and embedded in the everyday operations of designing and selling the service, which means that the service production and innovation processes take place simultaneously, and the market's problem, in its most pure sense, is the starting point of most innovation processes (Sundbo and Gallouj 2000). Besides, service-oriented organizations, such as bank, retail stores, insurance companies, etc. improve their capability for satisfying the wants and needs of the clients by first satisfying the wants and needs of the providers who serve them; in services, internal marketing paves the way for the external marketing (Berry 2016). Therefore, the relationship between service innovation and internal marketing emerges.

Internal marketing appeared as a tool and concept in the 1960s, which led to total quality management (Proctor and Doukakis 2003). In the 1970s, it presented as a way for firms to consider both their employees and their customers. It means that satisfying employees demonstrated more customer loyalty and profits for companies. Also, it shows the perspective on internal marketing evolved, for example, from a tool in an organization for quality management to as a decision making for the company's profit.

According to (Varey 1995), internal marketing emphasizes much on communication, which is too limited. It is only tactical because the focus relies on a viewpoint like 'marketing is about selling advertising.' On the other hand, this paper offered a review from a different perspective, i.e., which potential area in research may have a contribution to the evolution over the past few years. Therefore, this paper scrutinized the trend and potential variables between internal marketing and service innovation, signifying another substantial opportunity for research on internal marketing and its influence on innovation (Akroush et al. 2013; Alambro 2013; Mieres et al. 2012).

Besides, Ahmed and Rafiq (2003) provided an interesting commentary on internal marketing issues and challenges, that is, too little attention has been paid to process organization and process issues within research in internal marketing since scholars have a high tendency to examine marketing activities than these elements.

Therefore, due to this gap in the literature, this study proposed to discuss two research questions: "What are the trends in internal marketing and service innovation study?" and "What aspects of internal marketing influence the service innovation between the period of study?". The main goal of this research was to draw trends over time in marketing and service innovation shown in the literature that influences service innovation. We also discussed the few related issues to this study, state of the art, and possibilities for future research.

The paper is structured as follows. First, we reviewed both kinds of literature in service innovation and internal marketing. Second, we systematically identified the potential variables that arise from both areas in the literature using specific criteria proposed. Third, we analyzed the trends in publications, such as on objectives, theoretical frameworks, methodologies, and potential variables, that are emerged and connected between internal marketing and service innovation. Fourth, we presented our findings and provided readers with the answers to the research questions raised. Finally, we concluded this paper with a discussion, contribution to knowledge, and practical implications.

\subsection{Theoretical Background}

The theoretical basis of internal marketing is multidisciplinary (Sievers et al. 2015). However, there are areas to strengthen theoretical rigor that is underpinning from the internal marketing concept. The understanding of trend and potential variables in this study may influence relevant existing theories and add discussion on theory building in this area of study.

\subsubsection{Internal Marketing}

Internal marketing, proposed to the services industries and its fundamental concept, originated in the 1980s (Barzoki and Ghujali 2013). Grönroos (2000), in his popular model of the internal market, suggested that internal marketing should operate as a process aimed to ensure the customer-oriented mindset among the employees and keep them motivated to deliver the highest standards in customer 
service. In contrast, Varey and Lewis (1999) described that the popular internal marketing theory might be too simplistic to be of real value. On the other hand, Ueno (2010) defined that the fundamental focus of internal marketing is on employees in the organization 'whose function is to provide, produce, or perform services to internal and external customers' (p. 75).

Meanwhile, Sadeghloo et al. (2014) emphasized that internal marketing starts when the organization recruits potential employees to develop them to achieve their personal goals and organizational mission, and the employees are expected to give high commitment and improve job performance, gratifying the customers. This concept is aligned with the theory of Grönroos (1981) that every employee of the organization has their internal customer and that they in reciprocal also have internal customers; while employer has some crucial duties to give benefit, preserve rights, and provide extra rewards for their employees, which in return give the better performance to the organization overall in the external market. Besides, internal marketing is an integral part of organizations and is described as a significant driver of internal service quality (ISQ) and external customer satisfaction (Akroush et al. 2013).

Internal marketing, as indicated by Yalabik et al. (2013), tends to increase work engagement by creating job satisfaction. Ahmed et al. (2003) highlighted that in such dynamic and changeable service-oriented organizations, such as banks, employees, who engage more in their work and organizational activities, act as agents to implementing corporate strategies in order to achieve organizational goals. Also, according to research investigated by Bailey et al. (2016), in the banking industry, internal marketing has an indirect effect between job satisfaction and commitment.

On the other hand, although most literature in internal marketing agrees with its fundamental concept, there are two different approaches to study this concept (Ueno 2010). Most of the literature reviews that we gathered explain that internal marketing concept means to treat employees like customers and, therefore, the essential marketing mix, such as product, price, promotion, place, and the additional Ps, are applicable within the firm (Collins and Payne 1991; Rafiq and Ahmed 1993; Varey 1995). In contrast, Gilmore and Carson (1995) explained that it is unlikely to cover all the internally related issues needed using marketing mix in order to thrive in the external environment, such as recruitment and selection, training, teamwork, empowerment, performance appraisals/measurement, communication, and culture. However, previous studies recommend for future research to examine which elements in internal marketing are more critical to service innovation than others (Ueno 2010). It is the niche area in the internal marketing theory that we intended to investigate.

Moreover, (Jung et al. 2016) explained that internal marketing is used by firms to inspire employees' capabilities as internal customers and also to respond to organizational goals. However, both managerial and academic debates on variables between internal marketing and service innovation of firms' activities are on-going even after more than 40 years. While conducting this research, the strength of possible variables that link between these two areas was identified and highlighted. This study aimed to close this gap by providing niche knowledge on the relationship between internal marketing and service innovation. This niche knowledge is the systematic review of internal marketing influencing service innovation that consists of trends over time (period of the study).

\subsubsection{Service Innovation}

Innovation in services becomes a crucial factor for an economy's innovativeness and competitiveness (Preissl 2000). The significance of scrutinizing service innovation is that there is a radical shift in a growing number of companies in the world in the way they manage and measure success (Heskett et al. 1994). As stated by Lusch and Nambisan (2015), the banking industry with service innovation, such as service efficiency enhancement, increase customer communication channels, employee training and learning, digital marketing enhancement, etc., could achieve better performance and profit compared to those that do not.

Carlborg et al. (2014) investigated an empirical study of 128 articles published between 1986 and 2010 and found that the number of service innovation articles has sharply increased, with common 
broadest topics on offering development and strategy and management. Barras (1986) demonstrated that there are no comprehension reviews that describe the evolution of service innovation research concerning the field of marketing and innovation. It is compelling evidence to examine the relationship between marketing and innovation. The existing studies show that service innovation is a primarily internal activity, which is managed and controlled by the firm and influenced by the firm's planned strategy (Carlborg et al. 2014). As highlighted by Groysberg and Slind (2012), the study of service innovation has been somewhat limited in various areas. Theoretically, actors in a firm can play a diverse set of roles in resource integration and service innovation, as well as proactively support the process of value co-creation by establishing new organizational mechanisms and making appropriate changes to their internal processes (Lusch and Nambisan 2015). However, there is no clear association between internal marketing and service innovation (Barras 1986). Furthermore, in-service-orientation and the need for greater organizational effectiveness have become significant debate topics, featuring sources of competitive advantages derived from changes in innovation.

In summary, the service innovation that we defined in this work refers to an idea for performance enhancement in any organization that is achieved through internal marketing. In doing so, internal marketing influences customer perspective based on their experience from the service provider not only with its experience but with its goods or services.

\subsubsection{Linking Internal Marketing and Service Innovation}

Scholars in this field are still debating on the measurement of the relationship between individual links in internal marketing. However, some of them have illustrated the link in a different lens that might be less considered, which can lead to comprehensive strategies in achieving competitive advantage. According to Pitt and Foreman (1999), internal marketing activities on a service-focused can be directed toward the employees or specific departments, functions, or groups. Ahmed et al. (2003) elaborated that these activities are called service-enabling internal marketing factors, such as communication, participative decision making, management commitment to quality service, service leadership, service training, and rewards and recognition.

Best of these concepts, Lings (Lings 2004) scrutinized the sets of actions and defined the internal marketing orientation. Based on his model, the firms are successful in implementing internal marketing dimensions, such as internal market research (Hollensen 2015), internal communications (Mishra et al. 2014), and internal responsiveness (Husted et al. 2000). This study follows the premise that internal marketing can enhance the firms' capability of generating service innovation. Therefore, the concept of internal market orientation is extremely important to understand how internal marketing can ignite service innovation. As Berry et al. (2006) pointed out, service innovation differs from product innovation in many ways. The most important for this work is that for labor-intensive, interactive services, which comprises most of the service innovation (Ordanini and Parasuraman 2011), the actual providers are part of the customer experience and thus part of the innovation. Figure 1 summarizes the internal market orientation discovered by Lings (2004).

We understand that these factors in internal marketing might lead to service innovation. However, there is limited research to support this finding in the area of study and to address the gaps we identified, and the present findings are too broad, and thus several scholars suggested for future research (Alambro 2013). The research finding by Lings (2004), as shown in Figure 1, leads to identifying the research questions for this study, which are close to the research gap identified.

In order to answer the research questions and address research gaps, we used a systematic review approach with appropriate procedures and criteria to examine the possible variables that are emerged from relevant collected papers and highlight their strong associations with evidence. 


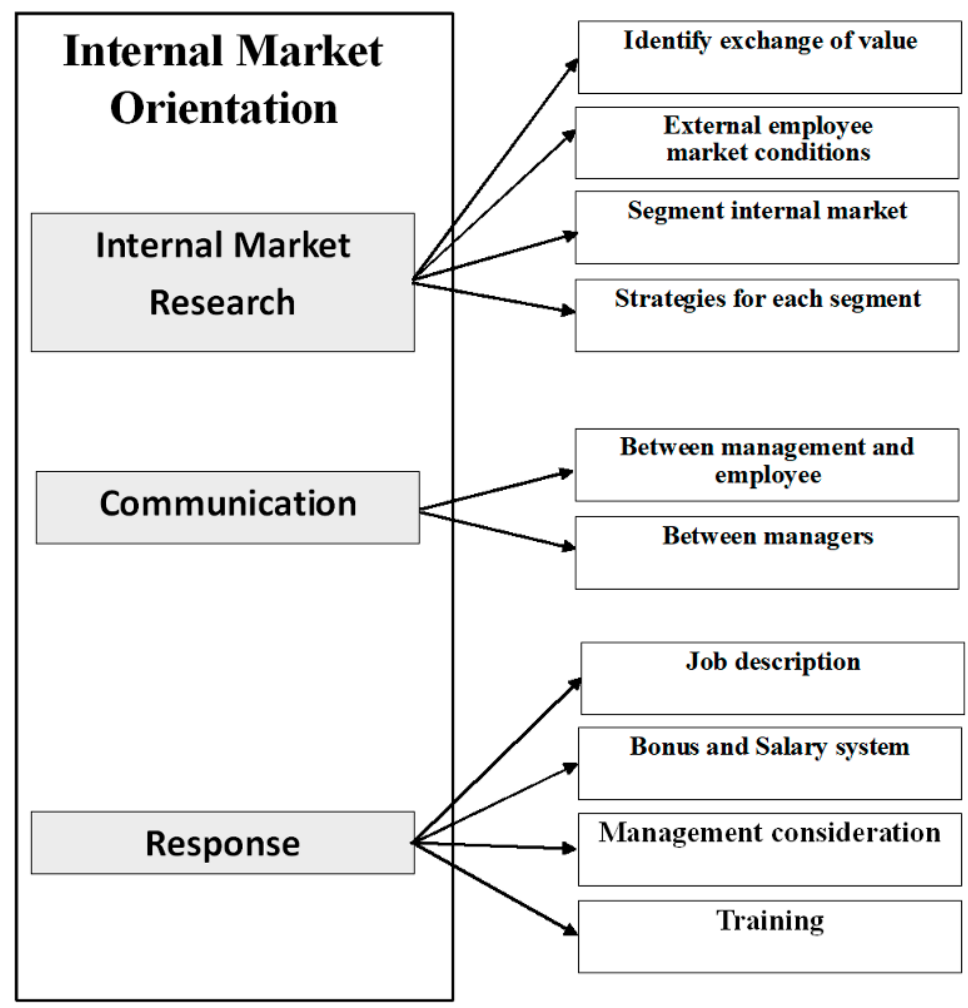

Figure 1. Dimensions of internal market orientation. Source: (Lings 2004). Reproduced with permission from Ian N. Lings, Journal of Business Research; published by Elsevier, 2004.

In sum, we know that employees rely on these three main vital factors, such as internal market, communications, and response. Ontologically, not all of the associating variables listed in Figure 1 might be crucial to service innovation. This claim is supported by Varey and Lewis (1999) that it is still an evolving subject on the service-orientation area, particularly between internal marketing and service innovation, and has become a significant topic of debate, featuring sources of competitive advantages, motivation, and purpose of the business organization.

\section{Materials and Methods}

In this study, we followed and adapted the systematic review protocols outlined by (Bossle et al. 2016; Petticrew and Roberts 2006; Sampaio and Mancini 2007; Tranfield et al. 2003) and specific methods to adapt to the social sciences research.

The systematic literature review is one of the methods which is useful for identifying the research gap because it "helps develop a reliable knowledge base by accumulating knowledge from a range of studies" (Hemsley-Brown and Oplatka 2006). The advantages of using a systematic review in this research shed light on three points. First, it helps to reduce the manageable research production for analysis by ensuring that the quality of selected papers is reliable evidence and within the scope of the study (Stead et al. 2007). Second, it provides a list of randomly gathered publications from reliable sources or library that may not be within the research scope of the phenomenon through a systematic multi-stage procedure. Third, it ensures that previous reviewers, to yield reliable evidence, have already judged all the studies, subsequently including sufficient methodological quality. Figure 2 illustrates the flowchart of the research protocol adopted in this study. 
Defining the scientific question specifying areas of interest

What are the aspects of internal marketing that influences service innovation?

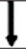

To identify database, define keywords, and search strategies

Scopus database, Keywords: internal marketing, service innovation

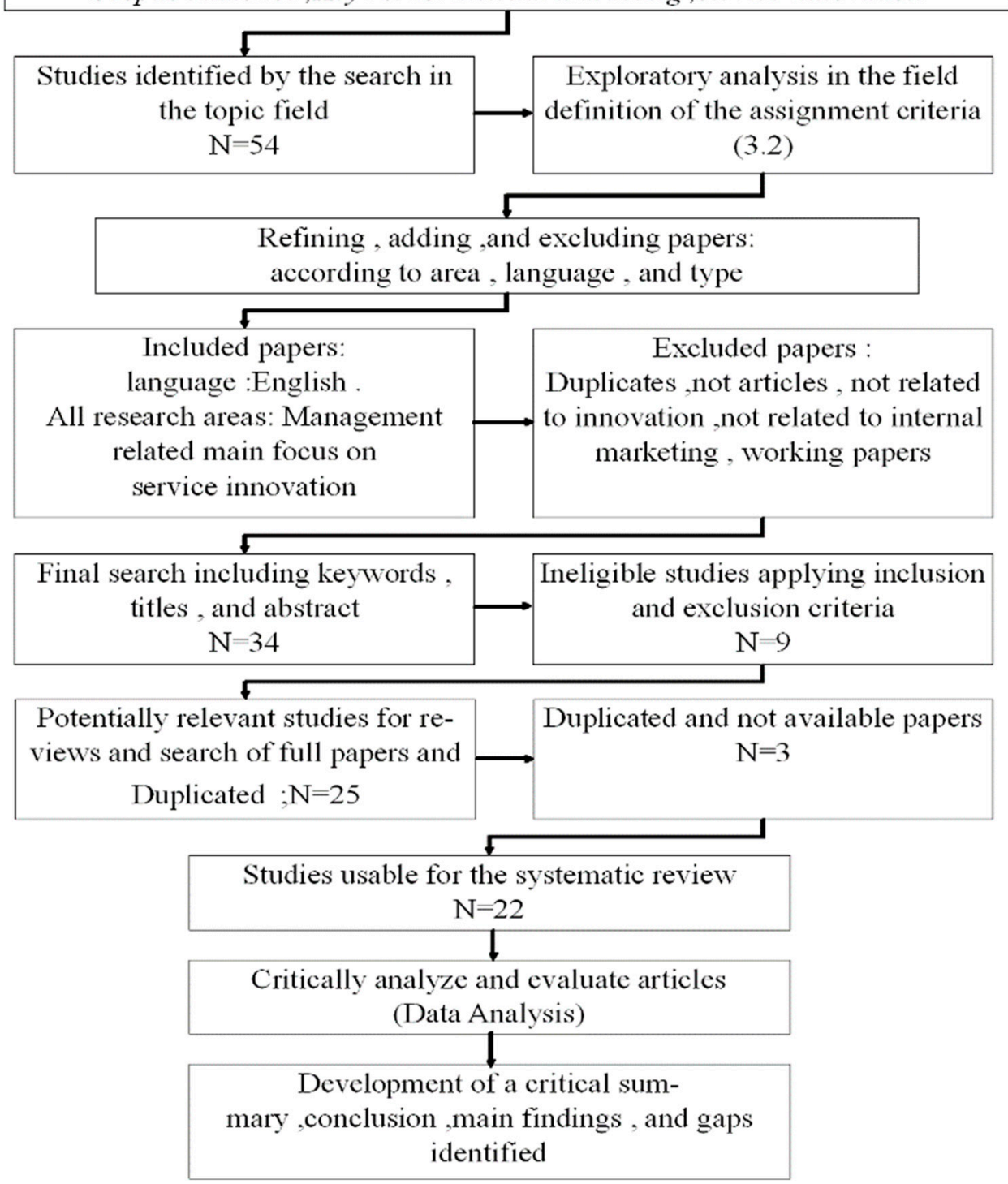

Figure 2. Systematic review-Procedures. Sources: Adapted from Bossle et al. (2016), Petticrew and Roberts (2006), and Sampaio and Mancini (2007).

Figure 2 shows the process of conducting a literature review systematically. Some steps have been designed to accomplish this purpose: (1) in order to delimit the appropriate literature review. Therefore, the following research criteria are helpful for this task:

- Search protocol: We used the Scopus library to collect the appropriate journals related to this study. Scopus is a user-friendly platform and allows us to create and use our parameters in its search engine. It informs every phase of the editorial process, and this strictness influenced our decision to choose Scopus.

- Main keywords: We used the main keywords, such as "internal marketing" and "service innovation." However, we did not consider papers where only one of these keywords was used. The reason we strictly focused on having both main keywords is that we wanted to investigate the fundamental core variables that link between them. Besides, we excluded conference papers, 
reviews, essays, and undefined documents that we once considered as working papers or not the final version.

- Year of publication: We sampled relevant articles that consist of the main keywords between 1990 and 2016. The reason we used the range between these periods is the rising demand in the area of study. Concerning the purpose of this research, the selected period of study between 1990 and 2016 is relevant because we wanted to see the changes of a trend in the area of study, as well as to identify the potential variables that link between internal marketing and service innovation.

- Language: We considered only articles published in English because the majority of journals with impact factor are in English, and due to the linguistic limitation.

- Quality: The reason we considered the journals with an impact factor is that we tried to be consistent with academic trends. However, this does not mean that other publications do not contribute or are less relevant for academic arenas. The significance of using journals with an impact factor is the validated knowledge in the field, so we feel that this criterion could provide an appropriate picture of the current issues and debates in internal marketing (Keupp et al. 2012).

After establishing the research criteria, the following step is to search for the relevant articles. First, the selection of the articles used the electronic database. Electronic searching focused on a single database that is Scopus. Second, electronically unavailable articles were excluded. Third, the main keywords on the subject were identified and constructed into search strings (Nielsen 2010). For example, the main keywords were "internal marketing" and "service innovation," so they combined into "internal marketing" "AND" "service innovation," which was used to reach the relevant articles. Fourth, these main keywords were used to search the relevant titles and abstracts. The first selection yielded 54 articles. Fifth, we scrutinized each of these articles by reading another round of the abstract and introduction to confirm that the articles were fit with identified criteria. Finally, we strictly selected those articles that fit the identified criteria. After this step, we identified only 22 articles that were finally useful for this systematic review. Besides, we did a manual check, and three papers were excluded from the sample due to duplicity and content incapability. As a result, we created an Excel workbook to separate and code the content of the objectives, potential variables that emerged, methodologies, definitions of the subject, and sources of each article from those selected 22 articles.

In contrast, this method has several limitations. First, the method has not always been systematic, and there is often insufficient information on the search strategy and inclusion criteria. In particular, reviews often fail to state explicitly how internal marketing is defined and conceptualized internal marketing in widely differing ways. We suggested that future researchers might consider additional criteria, for example, using the ABS (The Association of Business Schools) ranking journals to enhance the systematic selection of appropriate journals to review. Second, while efforts are made to avoid errors by combining both manual and computerized procedures, the quality of the original data cannot be guaranteed if the primary sources of failures are still data input errors. For example, if volume/page numbers are omitted, and irregular and cryptic journal abbreviations are used, an assignment to the correct reference-type category is impossible. Third, this study relied mainly on specific journals from a single database library. Some journals may use different types of citation index, making it challenging to create a standard to analyze. Therefore, we recommended future research to use more than two databases because it would provide great sources and robust findings from the systematic review, obtaining evidence.

\subsection{Data Sources and Mapping the Evidence}

After selecting the papers, we conducted an exploration suggested by Petticrew and Roberts (2006), where we extracted the data-potential variables that emerged and linked between internal marketing and service innovation. The Excel workbook was prepared to record and compare the content of data.

In terms of data sources, we found it is rather challenging to obtain a picture of all scientific outcomes, and scholars tended to select a dedicated database. The significant reason to select a 
particular database is to collect high-quality scientific articles. The database contains several thousand journals and provides citation counts between these journals. The more citation in a journal, the higher it has a scientific impact.

There are some advantages to using the Scopus library as a single database. First, Scopus is a library created by Elsevier. It is considered the largest abstract and citation database of peer-reviewed research literature, and it provides a search tool for a quick, easy, and comprehensive resource to support research needs in various disciplines of research. Second, it has more than 20,500 titles from more than 5000 international publishers and overall has approximately 49 million records. Therefore, it demonstrates the reliability, validity, quality, and accountability of Scopus, as a selected single database. Third, choosing the right library like Scopus is one of the fundamental elements in the systematic review, which is extremely important to perform a bibliometric analysis. Finally, when a pattern from one data source is corroborated by evidence from various high impact journals that are grouped in the same library, the finding is stronger, and it also provides a stronger base for theory-building (Eisenhardt 1989; Yin 2017).

\subsection{Procedures}

The procedures to perform the Systematic review are divided into three stages, namely, (1) planning the review, (2) conducting a review, and (3) reporting and dissemination. We followed 9 phases illustrated in Figure 3, adapted from the NHS (National Institute of Health Service Research) Center for Reviews and Dissemination.

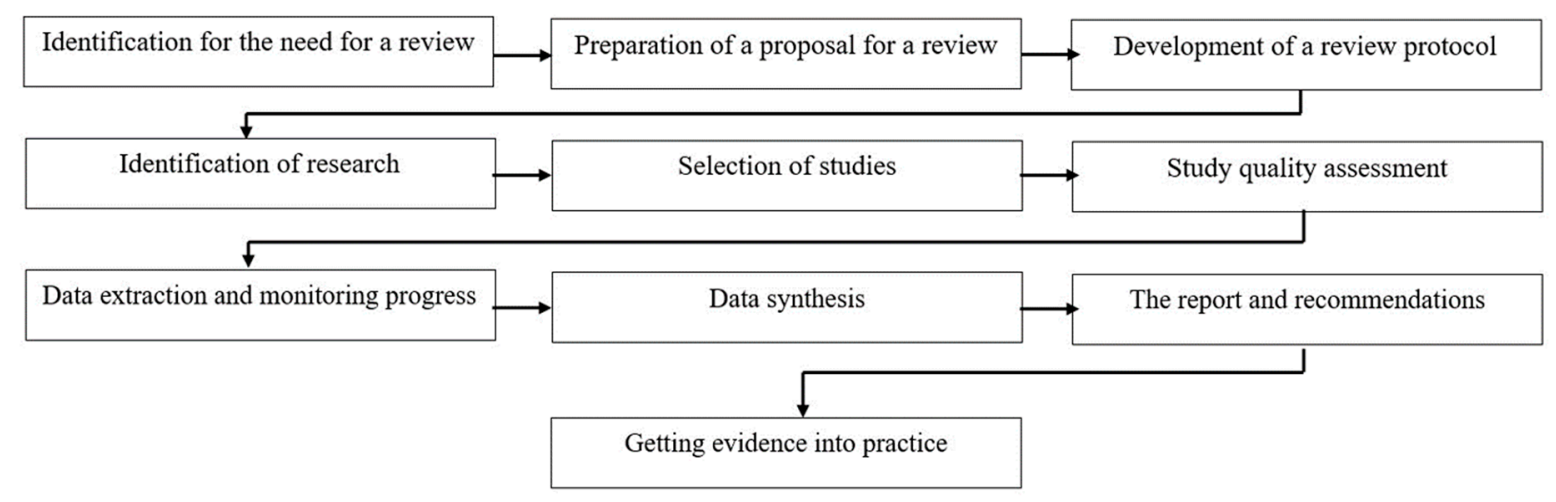

Figure 3. Stages of a systematic review. Source: Adapted from the research conducted in the NHS Center for Reviews and Dissemination by Bruce and Mollison (2004).

Figure 3 shows a summary of the procedure to perform the systematic review for this study by adopting a proposed guideline from Bruce and Mollison (2004). The data synthesis stage consumes much time because we carefully did a manual review between phase 4 (identification of research) and 8 (data synthesis). Besides, we created an Excel workbook manually for recording and comparing the data content while reviewing the selected articles. Also, we used three appropriate software to prepare the sample for this analysis phase, such as Endnote X8, Procite 5.0, and Mendeley. Finally, the third stage entails (9) the report and recommendations, and (10) getting evidence into practice. In sum, we found that the procedure described in Figure 3 to perform the systematic review is a practical design for this study because we could provide details of each phase.

\subsection{Data Analysis}

This section scrutinizes the process of data analysis in this study. The importance of this section is that it justifies the relevance of the research method in the previous discussion. This study used thematic analysis as a method for data analysis. The thematic analysis provides rich insights into complex phenomena within the period of the study and might apply across a range of theoretical and epistemological approaches (Braun and Clarke 2006). In contrast, thematic analysis is a poorly-defined 
and rarely acknowledged, yet widely used as a data analysis method that has criticisms for lacking depth (Attride-Stirling 2001; Roulston 2001). However, the purpose of this study was to present an overview of overall trends regarding objectives, theoretical frameworks, methodologies, and potential variables that connect internal marketing and service innovation. Furthermore, this study intends to answer the research questions. Therefore, we rejected the criticism of lacking depth as this applies to an in-depth investigation study like the case study research method, while we aimed to generate potential variables (in general), robustness, and reliability from selected articles.

We used thematic analysis to answer the research questions because it helps to form pattern recognition (potential variable emerged over time) from the selected articles, with the emerging theme becoming the categories for analysis (Fereday and Muir-Cochrane 2006). As we highlighted in the previous section, this process was extremely time-consuming as it involved careful, focused re-reading, and review of the data, which made it the most prolonged process in this study. In this section, we also adopted and modified criteria from Braun and Clarke (2006) in interpreting data for the findings. The data analysis process is summarized in Table 1.

Table 1. Phases of the thematic analysis.

\begin{tabular}{ll}
\hline \multicolumn{1}{c}{ Phase } & \multicolumn{1}{c}{ Description of the Process } \\
\hline (1) Familiarizing with the data collected: & $\begin{array}{l}\text { Reading and re-reading the selected articles collected from the } \\
\text { Scopus library. }\end{array}$ \\
\hline (2) Generating initial codes: & Coding the data in a systematic way for the entire data set. \\
\hline (3) Searching for themes: & Gathering all data relevant to each potential theme. \\
\hline (4) Reviewing themes: & Generating a thematic analysis. \\
\hline (5) Defining and naming themes: & $\begin{array}{l}\text { Ongoing analysis to refine the specific themes and overall story, } \\
\text { the analysis tells on internal marketing and service innovation. }\end{array}$ \\
\hline (6) Producing the report: & $\begin{array}{l}\text { Producing a report of the analysis with complete extract } \\
\text { examples and evidence, a final analysis of the selected extracts, } \\
\text { relating to the analysis of the research question and gaps. }\end{array}$ \\
\hline
\end{tabular}

Source: Adopted and modified from (Braun and Clarke 2006, p. 87).

\section{Results}

This study demonstrated two results, such as general findings and specific findings based on themes. In general, the research area between internal marketing and service innovation is still in demand. It arose from the rising numbers of the article published by the year between 1990 and 2016. The phenomenon of this area of study attracted not only publications from the English language but also other languages as well. However, we delimited our analysis of English articles only due to our limited knowledge of other languages. It clearly shows that scholars around the world are continuously debating on this topic from a different lens, and it is still patchy for theory building. Besides, we compiled evidence of the existing literature on potential variables that might connect between internal marketing and service innovation. In general, it highlights these potential variables for further investigation as well as to test its correlation, either for qualitative or quantitative research.

On the other hand, we scrutinized specific findings regarding overall trends, objectives, theoretical frameworks, methodologies, and potential variables that connect internal marketing and service innovation, such as motivation, organizational learning, and organizational culture. These specific findings had answered the research questions raised. However, these answers should be considered in light of several potential methodological limitations, as we mentioned before. As a reminder, the first question is, "What are the trends in internal marketing and service innovation study?". The answers appeared from data analysis by themes. We found there are trends in overall research, regarding objectives, regarding theoretical frameworks, and regarding methodologies. 


\subsection{Overall Trends}

Firstly, we presented specific findings on the theme of the overall trend. According to Figure 4, there is a growing interest in the association between internal marketing and service innovation. From 2011 to 2016, we had 14 papers published on the topic, which is more than the overall amount of papers published before 2011. In 2001, this topic was rose sharply to five papers published, explaining the beginning of a new trend in this research interest. The emerging trend gradually changed between before and after 2010. It illustrates that only a few researchers are aware and interested in exploring the relationship between internal marketing and service innovation. Several works (Akroush et al. 2013; Alambro 2013; Hernández 2008; Mieres et al. 2012) support this claim and they highlight that there is a little attention paid in this area with some suggestions for future research, particularly in exploring the potential variables emerged between internal marketing and service innovation.

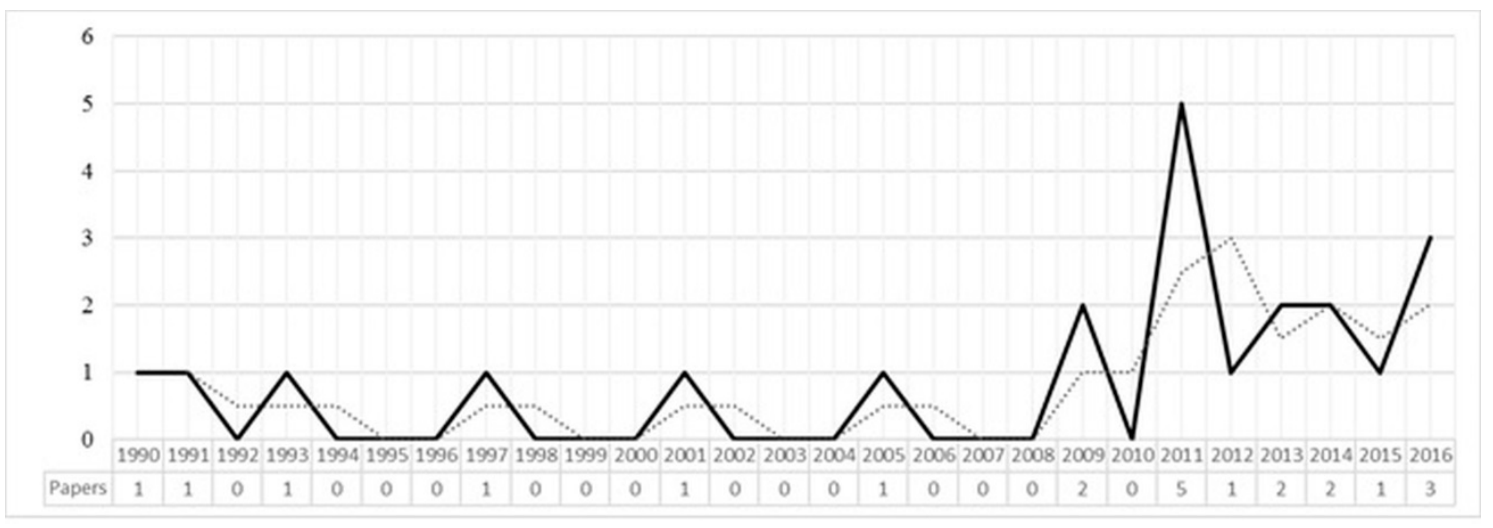

Figure 4. Papers published per year and moving average. Source: Data analysis from systematic review.

\subsection{Regarding Objectives}

Secondly, our specific finding scrutinized the objectives from 22 selected papers in this study. Based on the review of the objectives of previous studies, it summarized that the majority of the articles had analyzed internal marketing and service innovation in various service industries. The objectives from selected papers are divided into two groups: (1) exploring the phenomenon between internal marketing and service innovation, in general, and (2) investigate the factors contributing between internal marketing and service innovation.

In the early 1990s, the first group of scholars started to explore the phenomenon between internal marketing and service innovation. Hassan and Foltz (1990) had raised the marketing concept to be implemented in innovative service through internal marketing to help organizations to achieve competitive advantage. In the same vein, scholars consistently investigated the understanding of this phenomenon for improvement (Gupta and Rogers 1991). Besides, Shank and Gilbert (1994) aimed to find the rational way to implement an internal marketing approach through total service quality, which they suggested for future research on the possible necessary step. Freeman and Varey (1997) had explored the introduction of internal marketing among major UK distribution network companies that runs as a small business using framework analysis. According to these objectives of the early research, we found that scholars were still exploring the potential variables that are suitable and could potentially connect between internal marketing and service innovation as a fundamental in theory building. It derived from their research method on an exploratory study as well as a case study.

In contrast, research between 2000 and 2016 aimed to investigate the factors that contribute to internal marketing and service innovation based on the findings from the first group of scholars. It illustrates that the second group of scholars started to accept gradually the fundamental variables that connect internal marketing and service innovation (Boichuk and Menguc 2013; Deng and Gibson 2009; Furseth et al. 2010; Spetz and Keane 2009; Umashankar et al. 2011). On the other hand, some scholars suggested revising the fundamental variables, which link between internal marketing and service 
innovation (Srinivasan and Moorman 2005; Chen and Cheng 2012; Tsai and Wu 2015; Berry 2016). These scholars argued that other variables influence internal marketing in service innovation, such as motivation, supply chain, organizational culture, and organizational learning (Choi 2016; Mieres et al. 2012; Sanchez-Hernandez and Miranda 2011; Weng et al. 2012).

Therefore, we argued that a raising interest from scholars to revise and scrutinize potential variables, which connect internal marketing and service innovation, is high. Although the early scholars had discovered some fundamental variables, later scholars had provided empirical evidence as well as case studies from various service sectors for potential variables, which might amend in a research framework. It means that the other potential variables have become a vital feature of the current investigation in internal marketing and service innovation (Berry 2016). In summary, Table 2 shows the objectives of 22 selected papers for this investigation.

Table 2. Objectives from selected literature reviews.

\begin{tabular}{|c|c|}
\hline Authors & Objectives \\
\hline (Hassan and Foltz 1990) & $\begin{array}{l}\text { To apply the marketing concept internally to the diffusion and } \\
\text { implementation of innovative services, which can help organizations } \\
\text { to achieve an advantageous external market position. }\end{array}$ \\
\hline (Deng and Gibson 2009) & $\begin{array}{l}\text { To present and explain an empirically informed and illuminating } \\
\text { model of the underlying factors that enable effective cross-cultural } \\
\text { leadership. } \\
\text { To outline procedures that employ the heuristic value of the model } \\
\text { to assist current and future expatriate managers to develop the } \\
\text { personal and intrapersonal capacities that underlie effective } \\
\text { cross-cultural leadership. }\end{array}$ \\
\hline (Furseth et al. 2010) & $\begin{array}{l}\text { To consider the overall dynamics of innovation that adds value for } \\
\text { the customer of service industries. }\end{array}$ \\
\hline (Kuusisto and Riepula 2011) & $\begin{array}{l}\text { To develop yet limited empirical knowledge on the intensity of } \\
\text { customer interaction and specific customer roles in service } \\
\text { innovation processes. }\end{array}$ \\
\hline (Mieres et al. 2012) & $\begin{array}{l}\text { To investigate the influence of organizational unlearning and } \\
\text { internal marketing on innovation as well as the mediatory effect of } \\
\text { organizational unlearning in the internal marketing-innovation link. }\end{array}$ \\
\hline (Freeman and Varey 1997) & $\begin{array}{l}\text { To explore the introduction of an internal marketing's way of } \\
\text { working in a business unit of a major UK distribution network } \\
\text { company, it runs as a small business. }\end{array}$ \\
\hline (Gupta and Rogers 1991) & $\begin{array}{l}\text { To improve understanding of the problem of integrating R\&D and } \\
\text { marketing in the new product development environment. }\end{array}$ \\
\hline (Srinivasan and Moorman 2005) & $\begin{array}{l}\text { To argue that a firm's strategic commitments may be an overlooked } \\
\text { organizational factor that influences the rewards for a firm's } \\
\text { investments in CRM (Customer Relationship Management). }\end{array}$ \\
\hline (Megicks et al. 2005) & $\begin{array}{l}\text { To assess the effects of market orientation on small retailer } \\
\text { performance in the UK, particularly in terms of how this facilitates } \\
\text { the development of market-led strategies, which may arguably be a } \\
\text { critical factor in determining their future survival in an increasingly } \\
\text { dynamic and competitive environment. }\end{array}$ \\
\hline (Weng et al. 2016) & $\begin{array}{l}\text { To investigate how the internal marketing perception of nurses } \\
\text { could have a significant positive moderating effect on the } \\
\text { relationship between service-oriented encounter and patient } \\
\text { satisfaction in nursing negligence. }\end{array}$ \\
\hline (Choi 2016) & $\begin{array}{l}\text { To focus on collaboration and coordination among the supply chain } \\
\text { in internal marketing in the service industry. }\end{array}$ \\
\hline (Rodríguez and Álvarez 2011) & $\begin{array}{l}\text { To achieve a deeper understanding of the internal marketing (IM) } \\
\text { concept, considered as an operant resource, according to the } \\
\text { service-dominant logic (SDL) theory, as well as to analyze the IM } \\
\text { contribution to the achievement of competitive advantage. }\end{array}$ \\
\hline (Chen and Cheng 2012) & $\begin{array}{l}\text { To understand the organizational and personal factors, motivating } \\
\text { employees to share knowledge. }\end{array}$ \\
\hline (Nakata et al. 2011) & $\begin{array}{l}\text { To understand the dynamics - antecedents, consequences, and } \\
\text { contingencies - of integration between these two groups. }\end{array}$ \\
\hline
\end{tabular}


Table 2. Cont.

\begin{tabular}{ll}
\hline \multicolumn{1}{c}{ Authors } & \multicolumn{1}{c}{ Objectives } \\
\hline (Sanchez-Hernandez and Miranda 2011) & $\begin{array}{l}\text { To present the first empirically tested model, showing that internal } \\
\text { marketing (IM) is a factor of success in new service development. }\end{array}$ \\
\hline Thomson and Hecker 2001) & $\begin{array}{l}\text { To explore what staff buy-in really means and how it ultimately } \\
\text { affects customers, using the findings of two significant surveys } \\
\text { commissioned by MCA (Management Consulting Association) and } \\
\text { conducted by MORI (Market and Opinion Research International). }\end{array}$ \\
\hline (Tsai and Wu 2015) & $\begin{array}{l}\text { To explore the structural relationships among internal marketing, } \\
\text { organizational commitment, and service quality and to practically } \\
\text { apply the findings. }\end{array}$ \\
\hline (Shank and Gilbert 1994) & $\begin{array}{l}\text { To develop the rationale for total service quality (TSQ) based on an } \\
\text { internal marketing approach (IMA), as well as to posit the steps } \\
\text { necessary to implement an IMA. }\end{array}$ \\
\hline (Berry 2016) & $\begin{array}{l}\text { To explore the relevance of these ideas three decades later and } \\
\text { discuss what should change and what should add. }\end{array}$ \\
\hline (Umashankar et al. 2011) & $\begin{array}{l}\text { To examine the effects of new service development (NSD) } \\
\text { characteristics on "internal innovation magnitude, defined as the } \\
\text { extent to which an internal customer service innovation offers } \\
\text { superior benefits to customer service agents relative to the existing } \\
\text { customer service practice. }\end{array}$ \\
\hline (Boichuk and Menguc 2013) & To explore job dissatisfaction is an epidemic in the retail industry. \\
\hline (Spetz and Keane 2009) & $\begin{array}{l}\text { To investigate the implementation and evaluation process of an } \\
\text { integrated hospital using the IT system among staff. }\end{array}$ \\
\hline
\end{tabular}

Sources: Table developed by the authors.

\subsection{Regarding Theoretical Frameworks}

Thirdly, we identified and classified the selected literature according to their nature. Two main groups considered those that have used (1) a literature review and those that have built (2) theoretical frameworks. We found that 16 selected papers were based on theoretical frameworks, while another six selected papers used a literature review of previous studies related to the subject under study. For instance, some studies focused on marketing theories, such as internal marketing theory, internal market orientation, marketing mix theory, service innovation theory, communication theory, and service-domain-logic theory (Choi 2016; Freeman and Varey 1997; Furseth et al. 2010; Rodríguez and Álvarez 2011; Sanchez-Hernandez and Miranda 2011; Thomson and Hecker 2001; Umashankar et al. 2011).

Besides, some scholars expanded their research using other business management theories to investigate the phenomenon from the other perspectives, such as transformational leadership (TL), role theory, organizational culture, organizational theory, and institutional theory (Boichuk and Menguc 2013; Chen and Cheng 2012; Deng and Gibson 2009; Spetz and Keane 2009; Tsai and Wu 2011).

On the other hand, the review also revealed a heavy reliance on sociological theories, as illustrated in Table 3, which have enriched the understanding of the topic like emotional intelligence (EQ), cultural intelligence (MacLaverty et al. 2007), dramaturgical theory, and complementarity theory (Deng and Gibson 2009; Nakata et al. 2011; Weng et al. 2016).

We identified that the individual level of analysis is a common trend in research on internal marketing and service innovation. There were six articles found from 22 selected papers. We recommended that it is worth to compare the individual levels of study rather than focus on one particular individual study. The comparative study might contribute new insights through studying the phenomena from a different lens, and it is useful to close gaps identified within the general analysis.

We believed that the individual level of analysis is crucial because it helps us to understand the heterogeneity of internal marketing and its potential variables upon service innovation. However, we also suggested that future research should take into account the macro-levels because the original context plays a significant role in the development of theory building for internal marketing in 
service innovation. In doing this, it helps to underpin the relevant study on internal marketing in service innovation.

In summary, we found that studies that relied on literature review were in favor to use internal marketing communication, service innovation, $R \& D$ marketing integration from a diffusion-of-innovation, customer relationship management (CRM) investment, marketing strategy and policy perspective, and internal marketing (Berry 2016; Gupta and Rogers 1991; Hassan and Foltz 1990; Kuusisto and Riepula 2011; Megicks et al. 2005; Mieres et al. 2012).

Finally, this review showed that some articles are descriptive, limited to particular space and time, and focused on specific service industries, such as tourism, hospital, and retail industry. Therefore, there is a shortage in theory building that needs extensive work to understand this phenomenon, for example, from other industries.

Table 3. Scrutinizing the theoretical sections in the papers.

\begin{tabular}{|c|c|c|}
\hline Groups & Theoretical Section & Number of Articles \\
\hline & Literature Reviews & \\
\hline & Internal Marketing Communication & \\
\hline & New Service Development & \\
\hline & Service Innovation & \\
\hline & R\&D Marketing Integration from a Diffusion-of-Innovation & \\
\hline & Customer Relationship Management (CRM) Investment & \\
\hline & Marketing Strategy and Policy Perspective & \\
\hline & Internal Marketing & \\
\hline \multirow{18}{*}{2} & Theoretical Frameworks & \multirow{18}{*}{16} \\
\hline & Transformational Leadership (TL) & \\
\hline & Emotional Intelligence (EQ) & \\
\hline & Cultural Intelligence (MacLaverty et al. 2007) & \\
\hline & Service Innovation Theory & \\
\hline & Modern Motivational Theory & \\
\hline & Communication Theory & \\
\hline & Integration of Marketing and Human Resource Management Theory & \\
\hline & Dramaturgical Theory & \\
\hline & Role Theory & \\
\hline & Marketing Mix Theory & \\
\hline & Service Domain Logic Theory & \\
\hline & Internal Marketing Theory & \\
\hline & Organizational Culture & \\
\hline & Complementarity Theory & \\
\hline & Institutional Theory & \\
\hline & Internal Market Orientation & \\
\hline & Organizational Theory & \\
\hline
\end{tabular}

Sources: Table developed by the authors.

\subsection{Regarding Methodologies}

Fourthly, methodologies and methods varied among the 22 selected papers. It is because they are consistent with the objectives and with the kind of data used. As shown in Table 4, we could see that survey is the most frequent method used in these selected papers (Chen and Cheng 2012; Choi 2016; Nakata et al. 2011; Rodríguez and Álvarez 2011; Sanchez-Hernandez and Miranda 2011; Thomson and Hecker 2001; Tsai and Wu 2011; Weng et al. 2016). The authors used a survey method to demonstrate how the influence variables in internal marketing interact with service innovation. It followed by a framework analysis method described in four papers (Freeman and Varey 1997; Gupta and Rogers 1991; Megicks et al. 2005; Srinivasan and Moorman 2005). The other researchers used a case study, empirical study, and theoretical methods to investigate the phenomenon. However, a limited study 
used a mixed-method, secondary analysis data, and experiment. It is crucial to have a balanced number of studies that use various methods because it would avoid bias, give vibrancy in the area of study, and provide a stronger base for theory-building (Eisenhardt 1989; Yin 2017).

Table 4. Identifying the methods from selected papers.

\begin{tabular}{lll}
\hline \multicolumn{1}{c}{ Authors } & \multicolumn{1}{c}{ Method } & \multicolumn{1}{c}{ Source } \\
\hline (Hassan and Foltz 1990) & Case Study & Journal of Hospital Marketing \\
\hline (Deng and Gibson 2009) & Case Study & ICIII 2009 \\
\hline (Kuusisto and Riepula 2011) & Case Study & ISPIM Conference 2010 \\
(Mieres et al. 2012) & Empirical Study & $\begin{array}{l}\text { International Journal of Technology } \\
\text { Management }\end{array}$ \\
\hline (Freeman and Varey 1997) & Empirical Study & International Journal of Management \\
(Gupta and Rogers 1991) & Framework Analysis & Marketing Intelligence \& Planning \\
(Srinivasan and Moorman 2005) & Framework Analysis & Journal of Services Marketing \\
\hline (Wegicks et al. 2005) & Framework Analysis & Journal of Service Research \\
(Choi 2016) & Framework Analysis & International Journal of Bank \\
(Rodríguez and Álvarez 2011) & Survey & Marketing \\
(Chen and Cheng 2012) & Survey & ActaPaulista de Enfermagem \\
& Survey & Nonprofit Management and \\
(Nakata et al. 2011) & Survey & Leadership \\
(Sanchez-Hernandez and Miranda & Cuadernos de Gestión \\
2011) & Survey & International Journal of Hospitality \\
(Thomson and Hecker 2001) & Survey & Management \\
(Tsai and Wu 2015) & Survey & Journal of the Academy of Marketing \\
\hline (Shank and Gilbert 1994) & Theoretical & European Journal of Innovation \\
(Berry 2016) & Theoretical & Management \\
\hline (Umashankar et al. 2011) & Analysis of Secondary Data & Journal of Service Research \\
\hline (Boichuk and Menguc 2013) & Experiment & Journal of Communication \\
\hline (Spetz and Keane 2009) & Mixed Methods & Management \\
\hline & Source Table developed by the autho \\
\hline
\end{tabular}

Source: Table developed by the authors.

In contradiction, as illustrated in Table 4, we advocated the use of qualitative research and mixed methods to investigate internal marketing in service innovation as it provides a more nuanced understanding of the phenomenon. In contrast to empirical study, we suggested future researchers conduct the phenomenon using case studies, grounded theory, theoretical, and secondary analysis data as methods to research on sensitive topics that could not be quantifiable and for creating theories that could explain this phenomenon.

Finally, we considered that both quantitative and qualitative studies are lacking because this topic is considered new and slightly of interest to marketing researchers. We also welcome future research on the positivist approach, combined with the interpretive and post-modernist paradigms.

As a reminder for the second question, "What variables of internal marketing that influence service innovation?" In the analysis, we found three potential variables that emerged from our samples, such as motivation, organizational learning, and organizational culture. In contrast, other potential variables appeared either in internal marketing or service innovation areas, such as communication and knowledge sharing. However, these variables did not meet the criteria in this study, and therefore, we excluded them from the further discussion for future research. We have presented our overall findings on potential variables in Table 5 below. 
Table 5. Key dimensions and sources.

\begin{tabular}{|c|c|}
\hline \multicolumn{2}{|r|}{ Internal Marketing } \\
\hline Key Dimension & Sources \\
\hline Communication & $\begin{array}{l}\text { (Kang et al. 2016; Liu et al. 2017; Rodríguez and Álvarez 2011; } \\
\text { Sanchez-Hernandez and Miranda 2011; Thomson and Hecker 2001) }\end{array}$ \\
\hline Motivation * & $\begin{array}{l}\text { (Berry 2016; Boichuk and Menguc 2013; Liu et al. 2017; Nakata et al. 2011; } \\
\text { Rodríguez and Álvarez 2011; Sanchez-Hernandez and Miranda 2011; Spetz and } \\
\text { Keane 2009; Thomson and Hecker 2001; Tsai and Wu 2011; Wang et al. 2012) }\end{array}$ \\
\hline Organizational Learning * & $\begin{array}{l}\text { (Freeman and Varey 1997; Gupta and Rogers 1991; Kuo et al. 2009; Kuusisto and } \\
\text { Riepula 2011; Liu et al. 2017; Megicks and Warnaby 2008; Mieres et al. 2012; } \\
\text { Nakata et al. 2011; Rodríguez and Álvarez 2011; Wang et al. 2012) }\end{array}$ \\
\hline Organizational Culture * & $\begin{array}{l}\text { (Freeman and Varey 1997; Gupta and Rogers 1991; Kuusisto and Riepula 2011; } \\
\text { Mieres et al. 2012; Nakata et al. 2011; Rodríguez and Álvarez 2011; } \\
\text { Sanchez-Hernandez and Miranda 2011; Spetz and Keane 2009; Thomson and } \\
\text { Hecker 2001; Weng et al. 2012) }\end{array}$ \\
\hline \multicolumn{2}{|r|}{ Service Innovation } \\
\hline Key Dimension & Sources \\
\hline Motivation * & $\begin{array}{l}\text { (Berry 2016; Boichuk and Menguc 2013; Liu et al. 2017; Nakata et al. 2011; } \\
\text { Rodríguez and Álvarez 2011; Sanchez-Hernandez and Miranda 2011; Spetz and } \\
\text { Keane 2009; Tsai and Wu 2011; Umashankar et al. 2011) }\end{array}$ \\
\hline Knowledge Sharing & $\begin{array}{l}\text { (Berry 2016; Boichuk and Menguc 2013; Freeman and Varey 1997; Gupta and } \\
\text { Rogers 1991; Megicks and Warnaby 2008; Mieres et al. 2012; Nakata et al. 2011; } \\
\text { Rodríguez and Alvarez 2011; Sanchez and Heene 1997; Spetz and Keane 2009; } \\
\text { Thomson and Hecker 2001; Tsai and Wu 2011; Umashankar et al. 2011; Weng et } \\
\text { al. 2012) }\end{array}$ \\
\hline Organizational Learning * & $\begin{array}{l}\text { (Choi 2016; Deng and Gibson 2009; Furseth and Cuthbertson 2013; Kuusisto } \\
\text { and Riepula 2011; Megicks and Warnaby 2008; Mieres et al. 2012; Nakata et al. } \\
\text { 2011; Rodríguez and Allvarez 2011; Spetz and Keane 2009; Srinivasan and } \\
\text { Moorman 2005; Weng et al. 2012) }\end{array}$ \\
\hline Organizational Culture * & $\begin{array}{l}\text { (Choi 2016; Kuusisto and Riepula 2011; Megicks and Warnaby 2008; Mieres et al. } \\
\text { 2012; Nakata et al. 2011; Rodríguez and Álvarez 2011; Sanchez-Hernandez and } \\
\text { Miranda 2011; Srinivasan and Moorman 2005; Weng et al. 2012) }\end{array}$ \\
\hline
\end{tabular}

Note: * this potential variable has a strong connection between internal marketing and service innovation. Source: Table developed by the authors.

We scrutinized these potential variables (communication, organizational learning, organizational culture, knowledge sharing, and motivation) according to our research criteria and identified three variables that appeared in the literature and met the criteria. We found reliable insights that demonstrate possibilities to link internal marketing and service innovation. Figure 5 illustrates the framework of our findings.

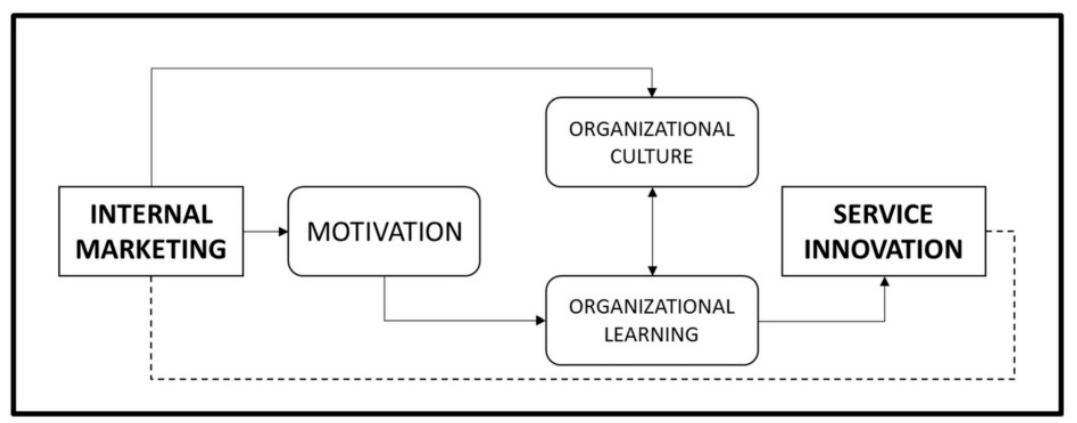

Figure 5. The link between internal marketing and service innovation. Source: Figure developed by the authors using findings in the systematic review. 


\subsection{Regarding Potential Variables}

Firstly, we identified that motivation envisaged as the first potential variable that connects between internal marketing and service innovation. This evidence was found from the work of early scholars between 1982 and 1990s, and it extended up to 2013 (Ahmed and Rafiq 2003; Ahmed et al. 2003; Akroush et al. 2013; George and Bettenhausen 1990; Hendriks 1999; Mitchell 1982; Robbins 1993).

We provided a claim that motivation is the most critical variable between the organization and the employee, representing attributes in internal marketing. The increasing motivation among attributes in internal marketing toward their job and their willingness in an organization would provide better customer service, which commonly perceives in the service industry. This potential variable is crucial from the beginning of research interest and is, still, in the debate because it provides essential foundations for understanding the role of the organization in influencing the employee's job attitudes and behaviors. The result supports our intention to contribute to a theoretical discussion that resource is vital for a firm's performance by considering internal marketing in service innovation. We believed that highlighting this point could strengthen the foundation attribute of a firm's performance that is motivation in human resources.

Secondly, we recognized that organizational learning is another crucial variable in connecting internal marketing and service innovation. Following the first variable, the organizational learning also appeared between 1990 and 2017 in internal marketing and service innovation research (Cui et al. 2013; Gupta and Rogers 1991; Hassan and Foltz 1990; Kahn and Mentzer 1998; Kearns and Lederer 2003; Lings 1999; Pantouvakis and Bouranta 2013; Rebelo et al. 2017; Sundbo and Gallouj 2000). According to them, organizational learning helps the employee to understand the organization functions as a default knowledge while working at a company, and it is deeply related to innovation as it defines the way that the knowledge acquired from internal and external sources flows inside the organization.

From our data analysis, researchers in the 1990s and 2000s, who used to debate on issues between internal marketing and service innovation, maintained their interest in organizational learning as fundamental variables. Moreover, we argued that understanding the nature of organizational learning is critical to understand how the organization process market information in order to reach competitive advantage and external marketing.

Thirdly, we acknowledged that organizational culture is also a potential variable that links internal marketing and service innovation. From our 22 selected papers, this variable was visible in research as early as in 1990 and consistently appeared up to 2013 (Freeman and Varey 1997; Kim and Lee 2006; McMurray et al. 2013; Schein 1990a; Tsai and Wu 2011). Although market and learning orientations are both separate antecedents of an innovative culture, we believed that organizations whose cultures emphasize innovation when resources are available, especially with high or consistent motivation, tend to implement more innovations and develop a competitive advantage. We have summarized the potential variables that emerged in our sample in Table 6. 
Table 6. Potential variables that emerged in internal marketing and service innovation between 1990 and 2017.

\begin{tabular}{|c|c|c|}
\hline Potential Variables & Definitions/Relations & Sources \\
\hline \multirow{4}{*}{ Motivation } & Definition & \multirow[b]{2}{*}{$\begin{array}{l}\text { (Ahmed et al. 2003; } \\
\text { Akroush et al. 2013; } \\
\text { Hendriks 1999; } \\
\text { Mitchell 1982; Robbins } \\
\text { 1993) }\end{array}$} \\
\hline & $\begin{array}{l}\text { Motivation represents "those psychological process } \\
\text { that causes the arousal, direction, and persistence of } \\
\text { voluntary actions that are goal-oriented. Motivation } \\
\text { is the willingness to exert high levels of effort toward } \\
\text { organizational goals, conditioned by the effort's } \\
\text { ability to satisfy some individual needs". }\end{array}$ & \\
\hline & $\begin{array}{l}\text { Influence of Internal Marketing and Service } \\
\text { Innovation }\end{array}$ & \multirow[b]{2}{*}{$\begin{array}{l}\text { (Ahmed and Rafiq 2003; } \\
\text { George and Bettenhausen } \\
\text { 1990; George 1990; } \\
\text { Kuusisto and Riepula 2011) }\end{array}$} \\
\hline & $\begin{array}{l}\text { As people may lack the motivation to follow formal } \\
\text { structures and procedures with the time, the internal } \\
\text { market becomes of the essence, and hence the } \\
\text { possibility of letting employees decide how to } \\
\text { provide service better, empowering them and } \\
\text { motivating so they can think the processes that they } \\
\text { are responsible for generating possibilities for service } \\
\text { innovation. }\end{array}$ & \\
\hline \multirow{4}{*}{$\begin{array}{l}\text { Organizational } \\
\text { Learning }\end{array}$} & Definition & \multirow[b]{2}{*}{$\begin{array}{l}\text { (Cui et al. 2013; Kahn and } \\
\text { Mentzer 1998; Kearns and } \\
\text { Lederer 2003; Lings 1999) }\end{array}$} \\
\hline & $\begin{array}{l}\text { Organizational learning is a process within } \\
\text { organizations that involves the interaction of } \\
\text { individual and collective (group, organizational, and } \\
\text { inter-organizational) levels of analysis and leads to } \\
\text { achieving organizations' goals. }\end{array}$ & \\
\hline & $\begin{array}{l}\text { Influence of Internal Marketing and Service } \\
\text { Innovation }\end{array}$ & \multirow[b]{2}{*}{$\begin{array}{l}\text { (Gupta and Rogers 1991; } \\
\text { Hassan and Foltz 1990; } \\
\text { Pantouvakis and Bouranta } \\
\text { 2013; Rebelo et al. 2017; } \\
\text { Sundbo and Gallouj 2000) }\end{array}$} \\
\hline & $\begin{array}{l}\text { To achieve the goals of organizational learning and } \\
\text { keeping their knowledge current, management must } \\
\text { ensure the integration, coordination, and cooperation } \\
\text { of internal organization functions. Organizational } \\
\text { learning might trigger a combination of } \\
\text { organizational culture and motivation. The } \\
\text { organizational learning is deeply related to } \\
\text { innovation as it defines the way that the knowledge } \\
\text { acquired from internal and external sources flows } \\
\text { inside the organization. }\end{array}$ & \\
\hline \multirow{4}{*}{$\begin{array}{l}\text { Organizational } \\
\text { Culture }\end{array}$} & Definition & \multirow[b]{4}{*}{$\begin{array}{l}\text { (Freeman and Varey 1997; } \\
\text { Kim and Lee 2006; } \\
\text { Tsai and Wu 2011) }\end{array}$} \\
\hline & $\begin{array}{l}\text { Organizational culture includes an organization's } \\
\text { expectations, experiences, philosophy, and values } \\
\text { that hold it together, and expressed in its self-image, } \\
\text { inner workings, interactions with the outside world, } \\
\text { and future expectations. It is based on shared } \\
\text { attitudes, beliefs, customs, and written and } \\
\text { unwritten rules that have been developed over time } \\
\text { and are considered valid. }\end{array}$ & \\
\hline & $\begin{array}{l}\text { Influence of Internal Marketing and } \\
\text { Service Innovation }\end{array}$ & \\
\hline & $\begin{array}{l}\text { Researchers have found that organizational culture } \\
\text { affects employees' knowledge-sharing attitudes and } \\
\text { behaviors. According to previous studies, there are } \\
\text { three elements of organizational culture to be related } \\
\text { to service innovation: clear mission and goals, trust, } \\
\text { and social networks. }\end{array}$ & \\
\hline
\end{tabular}




\section{Conclusions and Recommendations}

Overall, this paper suggests that internal marketing in service innovation is a promising area of research. Our findings have some academic implications.

First, we have developed a novel research methodology to study internal marketing and service innovation, which comprises themes, such as overall trends in the subject, regarding objectives, regarding theoretical frameworks, regarding methodologies, and regarding potential variables, that connect internal marketing and service innovation, such as motivation, organization learning, and organization culture. We believe that our methodology is the state-of-the-art of this paper while recommending for future research to consider limitations that emerged.

Second, we have highlighted potential variables that possibly connect between internal marketing and service innovation, which have consequences on the motivation, organizational learning, and organizational culture. It contributes to the internal marketing literature, addressing some gaps identified between 1990 and 2016. As for the theoretical implications, the framework we proposed has been partially supported by empirical evidence. However, there are rooms to improve it and to add dimensions that we might fail to cover.

Third, by emphasizing potential variables that link between internal marketing and service innovation, this research also contributes to the development of a broader innovation concept in internal marketing, which Lings (2004) used as the theoretical underpinning for internal market orientation.

\section{Managerial Implications}

This paper can help managers to redefine their roles and the relationship between members of the organization. Motivation is the anchor for human resources in an organization. According to (Tansuhaj et al. 1991), the significant role of internal marketing is to assure that employees feel that management cares about them and their needs. The application of this concept is translated into positive employees' attitudes towards their work, including organizational learning, job involvement, work motivation, and job satisfaction. Within our sample, many studies highlight motivation as a responsibility of internal marketing and as a fuel to ignite and maintain the organizational learning (Boichuk and Menguc 2013; Megicks et al. 2005; Nakata et al. 2011). Therefore, if dynamic service-oriented organizations (banks, retail stores, insurance companies, travel companies, financial service industry, etc.) wish to achieve the desired level of success, employees' motivation should be their first priority in order to create service innovation. Figure 5 fulfills the aim of this study. Service-oriented organizations can improve service innovation and competitive advantages through prioritizing internal marketing factors.

Besides, organizational learning is a default knowledge for all employees in an organization. In the same vein, researchers confirmed that the organizational learning is linked to organizational culture in a "both-ways" relation (Abbasi and Zamani-Miandashti 2013; Pantouvakis and Bouranta 2013; Rebelo et al. 2017). We know that organizational learning relies on motivation based on the existing literature; therefore, we believe that robust organizational learning may support the constant search for service innovation. It could be another point to be considered by the managers in order to boost employees' motivation. Furthermore, several studies argued that organizational learning is the main path by which the companies can acquire knowledge, from internal and external sources, and innovate in its services (Gupta and Rogers 1991; Hassan and Foltz 1990; Rodríguez and Álvarez 2011).

The findings from this systematic review can help managers and firms to innovate their business services to consider their improved organizational culture. Organizational culture is an adaption process of human resources from various cultural backgrounds in an organization. According to researchers, the organizational culture seems to be the common ground among most companies because service innovation emerges every day in multiple types of companies (Hogan and Coote 2014; Kindström and Kowalkowski 2014; Uzkurt et al. 2013). The findings from this paper support the idea that organizational culture plays a role in acting like a "tempo control" for service innovation. It means that service innovation is likely to occur in companies that have the innovation culture 
embedded in its daily routine. The role of internal marketing to support the service innovation is to establish an influential organizational culture, allowing the knowledge to flow inside the company and encouraging the employees to express themselves and to develop what is called the innovation capabilities (Ahmed et al. 2003; Rafiq and Ahmed 2000). In doing so, managers might ensure that every employee in all parts of the organization is involved in the delivery of quality throughout the customer-supplier chain services. Varey (1995) agreed with this as he highlighted that managers are increasingly looking to achieve suitable productivity gains from specialist internal services.

In conclusion, both general and specific findings from selected literature review present the significant reason to research internal marketing and service innovation. It shows that scholars are welcoming studies in this niche, albeit debating some issues, significant, and variables related to this area.

\section{Limitations}

Despite these contributions, this study also has limitations. While the mixed method approach has yielded nuanced and rich findings, the use of qualitative data and analysis, with limited sample sizes, potentially undermines the generalizability of findings. We would recommend future researchers to adopt larger-scale validation studies. The cross-sectional nature of our data has precluded investigation of the evolution of internal marketing on service innovation over time. However, we recommend the longitudinal research methodology in the future. In doing so, we hope that future studies could use our proposed methodology to test significant areas of internal marketing on service innovation as well as in a different context. The findings may strengthen the proposed methodology from this study.

Funding: This research was funded by the National Natural Science Foundation of China under Grant No.71771122.

Conflicts of Interest: The authors declare no conflict of interest.

\section{References}

Abbasi, Enayat, and Naser Zamani-Miandashti. 2013. The role of transformational leadership, organizational culture and organizational learning in improving the performance of Iranian agricultural faculties. Higher Education 66: 505-19. [CrossRef]

Afuah, Allan. 2002. Mapping technological capabilities into product markets and competitive advantage: The case of cholesterol drugs. Strategic Management Journal 23: 171-79. [CrossRef]

Ahmed, Pervaiz K, and Mohammed Rafiq. 2003. Internal marketing issues and challenges. European Journal of Marketing 37: 1177-86. [CrossRef]

Ahmed, Pervaiz K., Mohammed Rafiq, and Norizan M. Saad. 2003. Internal marketing and the mediating role of organisational competencies. European Journal of Marketing 37: 1221-41. [CrossRef]

Akroush, Mamoun N., Amjad A. Abu-ElSamen, Ghazi A. Samawi, and Abdelhadi L. Odetallah. 2013. Internal marketing and service quality in restaurants. Marketing Intelligence E Planning 31: 304-36.

Alambro, Ahmed. 2013. The Impact of Internal Marketing on NPD. Doha: College of Business and Economics, Qatar University, pp. 1-6. [CrossRef]

Attride-Stirling, Jennifer. 2001. Thematic networks: An analytic tool for qualitative research. Qualitative Research 1 : 385-405. [CrossRef]

Bailey, Ainsworth Anthony, Faisal Albassami, and Soad Al-Meshal. 2016. The roles of employee job satisfaction and organizational commitment in the internal marketing-employee bank identification relationship. International Journal of Bank Marketing 34: 821-40. [CrossRef]

Barras, Richard. 1986. Towards a theory of innovation in services. Research Policy 15: 161-73. [CrossRef]

Barzoki, Ali Shaemi, and Tohid Ghujali. 2013. Study the relationship of internal marketing with job satisfaction, organizational commitment and organizational citizenship behavior. International Journal of Academic Research in Business and Social Sciences 3: 33.

Bernstein, Steven L. 2005. Internal marketing of an ED-based public health initiative. The American Journal of Emergency Medicine 23: 411-13. [CrossRef] 
Berry, Leonard L. 2016. Revisiting “big ideas in services marketing” 30 years later. Journal of Services Marketing 30: 3-6. [CrossRef]

Berry, Leonard L., Venkatesh Shankar, Janet Turner Parish, Susan Cadwallader, and Thomas Dotzel. 2006. Creating new markets through service innovation. MIT Sloan Management Review 47: 56.

Boichuk, Jeffrey P., and Bulent Menguc. 2013. Engaging dissatisfied retail employees to voice promotive ideas: The role of continuance commitment. Journal of Retailing 89: 207-18. [CrossRef]

Bossle, Marilia Bonzanini, Marcia Dutra de Barcellos, Luciana Marques Vieira, and Loïc Sauvée. 2016. The drivers for adoption of eco-innovation. Journal of Cleaner Production 113: 861-72. [CrossRef]

Braun, Virginia, and Victoria Clarke. 2006. Using thematic analysis in psychology. Qualitative Research in Psychology 3: 77-101. [CrossRef]

Bruce, Julie, and Jill Mollison. 2004. Reviewing the literature: Adopting a systematic approach. BMJ Sexual $\mathcal{E}$ Reproductive Health 30: 13-16.

Carlborg, Per, Daniel Kindström, and Christian Kowalkowski. 2014. The evolution of service innovation research: A critical review and synthesis. The Service Industries Journal 34: 373-98. [CrossRef]

Chen, Wen-Jung, and Han-Yin Cheng. 2012. Factors affecting the knowledge sharing attitude of hotel service personnel. International Journal of Hospitality Management 31: 468-76. [CrossRef]

Choi, Tsan-Ming. 2016. Service Supply Chain Systems: A Systems Engineering Approach. Boca Raton: CRC Press.

Collins, Brett, and Adrian Payne. 1991. Internal marketing: A new perspective for HRM. European Management Journal 9: 261-70. [CrossRef]

Cui, Anna Shaojie, David A. Griffith, and S. Tamer Cavusgil. 2013. The influence of competitive intensity and market dynamism on knowledge management capabilities of multinational corporation subsidiaries. Journal of International Marketing 13: 32-53. [CrossRef]

Deng, Ling, and Paul Gibson. 2009. Mapping and modeling the capacities that underlie effective cross-cultural leadership: An interpretive study with practical outcomes. Cross Cultural Management: An International Journal 16: 347-66. [CrossRef]

Eisenhardt, Kathleen M. 1989. Building theories from case study research. Academy of Management Review 14: 532-50. [CrossRef]

Ellwood, Paul, Paul Grimshaw, and Krsto Pandza. 2017. Accelerating the innovation process: A systematic review and realist synthesis of the research literature. International Journal of Management Reviews 19: 510-30. [CrossRef]

Fereday, Jennifer, and Eimear Muir-Cochrane. 2006. Demonstrating rigor using thematic analysis: A hybrid approach of inductive and deductive coding and theme development. International Journal of Qualitative Methods 5: 80-92. [CrossRef]

Freeman, Sue, and Richard J. Varey. 1997. The effects of entrepreneur characteristics and gender-based management and communication styles from an internal marketing perspective, within both a small and large business environment. Marketing Education Review 7: 75-85. [CrossRef]

Furseth, Peder Inge, and Richard Cuthbertson. 2013. The service innovation triangle: A tool for exploring value creation through service innovation. International Journal of Technology Marketing 8: 159-76. [CrossRef]

Furseth, Peder Inge, Richard Cuthbertson, and Jonathan Reynolds. 2010. The value dynamics of service innovation. Paper presented at the 2010 ISPIM Conference, Bilbao, Spain, June 6-9.

George, William R. 1990. Internal marketing and organizational behavior: A partnership in developing customer-conscious employees at every level. Journal of Business Research 20: 63-70. [CrossRef]

George, Jennifer M., and Kenneth Bettenhausen. 1990. Understanding prosocial behavior, sales performance, and turnover: A group-level analysis in a service context. Journal of Applied Psychology 75: 698. [CrossRef]

Gilmore, Audrey, and David Carson. 1995. Managing and marketing to internal customers. Understanding Services Management 1995: 295-321.

Grönroos, Christian. 1981. Marketing of Services: A Study of the Marketing Function of Service Firms. Ann Arbor: University Microfilms Internat.

Grönroos, Christian. 2000. Creating a relationship dialogue: Communication, interaction and value. The Marketing Review 1: 5-14. [CrossRef]

Groysberg, Boris, and Michael Slind. 2012. Leadership is a conversation. Harvard Business Review 90: 76-84. [PubMed] 
Gupta, Ashok K., and Everett M. Rogers. 1991. Internal marketing: Integrating R\&D and marketing within the organization. Journal of Services Marketing 5: 55-68.

Hassan, Salah S., and Mary Beth Foltz. 1990. Health care innovations from the internal marketing perspective. Journal of Hospital Marketing 4: 97-117. [CrossRef]

Hemsley-Brown, Jane, and Izhar Oplatka. 2006. Universities in a competitive global marketplace: A systematic review of the literature on higher education marketing. International Journal of Public Sector Management 19: 316-38. [CrossRef]

Hendriks, Paul. 1999. Why share knowledge? The influence of ICT on the motivation for knowledge sharing. Knowledge and Process Management 6: 91. [CrossRef]

Hernández, María Isabel Sánchez. 2008. Internal marketing as a factor of success in new service development: An empirical approach. International Review on Public and Nonprofit Marketing 5: 81-82. [CrossRef]

Heskett, James L., Thomas O. Jones, Gary W. Loveman, W. Earl Sasser, and Leonard A Schlesinger. 1994. Putting the service-profit chain to work. Harvard Business Review 72: 164-74.

Hogan, Suellen J., and Leonard V. Coote. 2014. Organizational culture, innovation, and performance: A test of Schein's model. Journal of Business Research 67: 1609-21. [CrossRef]

Hollensen, Svend. 2015. Marketing Management: A Relationship Approach. London: Pearson Education.

Husted, Janice A., Richard J. Cook, Vern T. Farewell, and Dafna D. Gladman. 2000. Methods for assessing responsiveness: A critical review and recommendations. Journal of Clinical Epidemiology 53: 459-68. [CrossRef]

Jung, Seo-Yoon, Kyeong-Hyo Jung, and Jae-Ik Shin. 2016. The Effects of Market Orientation and Corporate Image on Organizational Performance through Internal Marketing: Focused on SMMs in South Korea. Available online: https://www.researchgate.net/publication/303995427_The_Effects_of_Market_Orientation_and_ Corporate_Image_on_Organizational_Performance_through_Internal_Marketing_Focused_on_SMMs_in_ South_Korea (accessed on 8 September 2020).

Kahn, Kenneth B., and John T. Mentzer. 1998. Marketing's integration with other departments. Journal of Business Research 42: 53-62. [CrossRef]

Kale, Sudhir H. 2007. Internal marketing: An antidote for Macau's labor shortage. UNLV Gaming Research $\mathcal{E}$ Review Journal 11: 1.

Kang, Hyoung Seok, Ju Yeon Lee, SangSu Choi, Hyun Kim, Jun Hee Park, Ji Yeon Son, Bo Hyun Kim, and Sang Do Noh. 2016. Smart manufacturing: Past research, present findings, and future directions. International Journal of Precision Engineering and Manufacturing-Green Technology 3: 111-28. [CrossRef]

Kearns, Grover S., and Albert L. Lederer. 2003. A resource-based view of strategic IT alignment: How knowledge sharing creates competitive advantage. Decision Sciences 34: 1-29. [CrossRef]

Keupp, Marcus Matthias, Maximilian Palmié, and Oliver Gassmann. 2012. The strategic management of innovation: A systematic review and paths for future research. International Journal of Management Reviews 14: 367-90. [CrossRef]

Kim, M.H., and J.H. Lee. 2006. The effects of internal marketing on service quality and customer satisfaction-Findings from empirical studies. Korean Journal of International Association, Area Studies 10: 388-408.

Kindström, Daniel, and Christian Kowalkowski. 2014. Service innovation in product-centric firms: A multidimensional business model perspective. Journal of Business $\mathcal{E}$ Industrial Marketing 29: 96-111.

Kuo, Ying-Feng, Chi-Ming Wu, and Wei-Jaw Deng. 2009. The relationships among service quality, perceived value, customer satisfaction, and post-purchase intention in mobile value-added services. Computers in Human Behavior 25: 887-96. [CrossRef]

Kuusisto, Arja, and Mikko Riepula. 2011. Customer interaction in service innovation: Seldom intensive but often decisive. Case studies in three business service sectors. International Journal of Technology Management 55: 171-86. [CrossRef]

Lings, Ian N. 1999. Balancing internal and external market orientations. Journal of Marketing Management 15: 239-63. [CrossRef]

Lings, Ian N. 2004. Internal market orientation: Construct and consequences. Journal of Business Research 57: 405-13. [CrossRef]

Liu, Weng-Kun, Yueh-Shian Lee, and Li-Mei Hung. 2017. The interrelationships among service quality, customer satisfaction, and customer loyalty: Examination of the fast-food industry. Journal of Foodservice Business Research 20: 146-62. [CrossRef] 
Lusch, Robert F., and Satish Nambisan. 2015. Service innovation: A service-dominant logic perspective. MIS Quarterly 39: 155-76. [CrossRef]

MacLaverty, Nina, Patricia McQuillan, and Hugh Oddie. 2007. Internal branding best practices study. Canadian Marketing Association 2: 2008.

McMurray, Adela J., Md Islam, James C. Sarros, and Andrew Pirola-Merlo. 2013. Workplace innovation in a nonprofit organization. Nonprofit Management and Leadership 23: 367-88. [CrossRef]

Megicks, Phil, and Gary Warnaby. 2008. Market orientation and performance in small independent retailers in the UK. The International Review of Retail, Distribution and Consumer Research 18: 105-19. [CrossRef]

Megicks, Philip, Atul Mishra, and Jonathan Lean. 2005. Enhancing microfinance outreach through market-oriented new service development in Indian regional rural banks. International Journal of Bank Marketing 23: 107-25. [CrossRef]

Mieres, Celina González, José Ángel López Sánchez, and Ma Leticia Santos Vijande. 2012. Internal marketing, innovation and performance in business services firms: The role of organizational unlearning. International Journal of Management 29: 403.

Mishra, Karen, Lois Boynton, and Aneil Mishra. 2014. Driving employee engagement: The expanded role of internal communications. International Journal of Business Communication 51: 183-202. [CrossRef]

Mitchell, Terence R. 1982. Motivation: New directions for theory, research, and practice. Academy of Management Review 7: 80-88. [CrossRef]

Nakata, Cheryl, Zhen Zhu, and Elif Izberk-Bilgin. 2011. Integrating marketing and information services functions: A complementarity and competence perspective. Journal of the Academy of Marketing Science 39: 700-16. [CrossRef]

Nielsen, Sabina. 2010. Top management team diversity: A review of theories and methodologies. International Journal of Management Reviews 12: 301-16. [CrossRef]

Ordanini, Andrea, and Ananthanarayanan Parasuraman. 2011. Service innovation viewed through a service-dominant logic lens: A conceptual framework and empirical analysis. Journal of Service Research 14: 3-23. [CrossRef]

Pantouvakis, Angelos, and Nancy Bouranta. 2013. The link between organizational learning culture and customer satisfaction: Confirming relationship and exploring moderating effect. The Learning Organization 20: 48-64. [CrossRef]

Petticrew, Mark, and Helen Roberts. 2006. How to appraise the studies: An introduction to assessing study quality. In Systematic Reviews in the Social Sciences: A Practical Guide. Hoboken: Wiley, pp. 125-63.

Pitt, Leyland F., and Susan K. Foreman. 1999. Internal marketing role in organizations: A transaction cost perspective. Journal of Business Research 44: 25-36. [CrossRef]

Preissl, Brigitte. 2000. Service innovation: What makes it different? Empirical evidence from Germany. In Innovation Systems in the Service Economy. New York: Springer, pp. 125-48.

Proctor, Tony, and Ioanna Doukakis. 2003. Change management: The role of internal communication and employee development. Corporate Communications: An International Journal 8: 268-77. [CrossRef]

Rafiq, Mohammed, and Pervaiz K. Ahmed. 1993. The scope of internal marketing: Defining the boundary between marketing and human resource management. Journal of Marketing Management 9: 219-32. [CrossRef]

Rafiq, Mohammed, and Pervaiz K. Ahmed. 2000. Advances in the internal marketing concept: Definition, synthesis and extension. Journal of Services Marketing 14: 449-62. [CrossRef]

Rebelo, Teresa, Teresa Rebelo, Adelino Duarte Gomes, and Adelino Duarte Gomes. 2017. Is organizational learning culture a good bet? An analysis of its impact on organizational profitability and customer satisfaction. Academia Revista Latinoamericana de Administración 30: 328-43. [CrossRef]

Robbins, Stephen P. 1993. Organizational Behavior: Concepts, Controversies, and Applications. Englewood Cliffs: Prentice Hall.

Rodríguez, Nuria García, and Begoña Álvarez Álvarez. 2011. Service Dominant Logic in the tourism sector: Internal marketing as an antecedent of. Cuadernos de Gestión 11: 53-75.

Roulston, Kathryn. 2001. Data analysis and 'theorizing as ideology'. Qualitative Research 1: 279-302. [CrossRef]

Sadeghloo, Maryam, Zahra Habibi Nodeh, and Robabe Rajabloo. 2014. The relationship between internal marketing and organizational commitment in Golestan's sports and youth offices. Advances in Applied Science Research 5: 316-19. 
Sampaio, Rosana F., and Marisa C. Mancini. 2007. Systematic review studies: A guide for careful synthesis of the scientific evidence. Brazilian Journal of Physical Therapy 11: 83-89. [CrossRef]

Sanchez, Ron, and Aimé Heene. 1997. Competence-Based Strategic Management: Concepts and Issues for Theory, Research, and Practice. Hoboken: Wiley.

Sanchez-Hernandez, M. Isabel, and Francisco J. Miranda. 2011. Linking internal market orientation and new service performance. European Journal of Innovation Management 14: 207-26. [CrossRef]

Schein, Edgar H. 1990a. Organizational Culture. Washington, DC: American Psychological Association, vol. 45.

Schein, Edgar H. 1990b. Organizational Culture: What it is and How to Change it. In Human Resource Management in International Firms. Berlin/Heidelberg: Springer, pp. 56-82.

Shank, Matthew D., and Faye W. Gilbert. 1994. An internal marketing approach to total service quality: A guide for practitioners. Journal of Hospital Marketing 8: 113-30. [CrossRef] [PubMed]

Sievers, Silvia, Carmen Valor, Lars Groeger, and Lara Moroko. 2015. Where is the marketing in internal marketing? Revisiting the concept from the Service-Dominant Logic perspective. Paper presented at the Innovation and Growth Strategies in Marketing, Sydney, Australia, November 20-December 2.

Spetz, Joanne, and Dennis Keane. 2009. Information technology implementation in a rural hospital: A cautionary tale. Journal of Healthcare Management 54: 337-48. [CrossRef]

Srinivasan, Raji, and Christine Moorman. 2005. Strategic firm commitments and rewards for customer relationship management in online retailing. Journal of Marketing 69: 193-200. [CrossRef]

Stead, Martine, Ross Gordon, Kathryn Angus, and Laura McDermott. 2007. A systematic review of social marketing effectiveness. Health Education 107: 126-91. [CrossRef]

Sundbo, Jon, and Faïz Gallouj. 2000. Innovation as a loosely coupled system in services. International Journal of Services Technology and Management 1: 15-36. [CrossRef]

Tansuhaj, Patriya, Donna Randall, and Jim McCullough. 1991. Applying the internal marketing concept within large organizations: As applied to a credit union. Journal of Professional Services Marketing 6: 193-202. [CrossRef]

Thomson, Kevin, and Lorrie Hecker. 2001. Value-adding communication: Innovation in employee communication and internal marketing. Journal of Communication Management 5: 48-58. [CrossRef]

Toivonen, Marja, Anssi Smedlund, and Tiina Tuominen. 2006. Development of Knowledge Intensive Business Service Innovations and Innovation Networks. Management: Journal for Management Theory and Practice 40: $4-11$.

Tranfield, David, David Denyer, and Palminder Smart. 2003. Towards a methodology for developing evidence-informed management knowledge by means of systematic review. British Journal of Management 14: 207-22. [CrossRef]

Troilo, Gabriele, Luigi M. De Luca, and Paolo Guenzi. 2017. Linking Data-Rich Environments with Service Innovation in Incumbent Firms: A Conceptual Framework and Research Propositions. Journal of Product Innovation Management 34: 617-39. [CrossRef]

Tsai, Yafang, and Shih-Wang Wu. 2011. Using internal marketing to improve organizational commitment and service quality. Journal of Advanced Nursing 67: 2593-604. [CrossRef] [PubMed]

Tsai, Yafang, and Shih-Wang Wu. 2015. New concept of nurse education for service innovation-a perspective of internal marketing. Paper presented at the 2015 International Conference on Industrial Engineering and Systems Management (IESM), Seville, Spain, October 21-23.

Ueno, Akiko. 2010. What are the fundamental features supporting service quality? Journal of Services Marketing 24: 74-86. [CrossRef]

Umashankar, Nita, Raji Srinivasan, and Dustin Hindman. 2011. Developing customer service innovations for service employees: The effects of NSD characteristics on internal innovation magnitude. Journal of Service Research 14: 164-79. [CrossRef]

Uzkurt, Cevahir, Rachna Kumar, Halil Semih Kimzan, and Gözde Eminoğlu. 2013. Role of innovation in the relationship between organizational culture and firm performance: A study of the banking sector in Turkey. European Journal of Innovation Management 16: 92-117. [CrossRef]

Varey, Richard J. 1995. Corporate Communication and Business Performance. Cheltenham: Stanley Thornes.

Varey, Richard J., and Barbara R. Lewis. 1999. A broadened conception of internal marketing. European Journal of Marketing 33: 926-44. [CrossRef] 
Wang, Cheng-Hua, Kuan-Yu Chen, and Shiu-Chun Chen. 2012. Total quality management, market orientation and hotel performance: The moderating effects of external environmental factors. International Journal of Hospitality Management 31: 119-29. [CrossRef]

Weng, Ming-Horng, Jih-Lian Ha, and Yi-Chou Wang. 2012. A study of the relationship among service innovation, customer value and customer satisfaction: An empirical study of the hotel industry in Taiwan. International Journal of Organizational Innovation (Online) 4: 98.

Weng, Hui-Ching, Tung-Mei Chen, Wei-Jing Lee, Ching-Sheng Chang, Chia-Tzu Lin, and Meng-Ling Wu. 2016. Internal Marketing and Its Moderating Effects between Service-Oriented Encounter and Patient Satisfaction. Acta Paulista de Enfermagem 29: 506-17. [CrossRef]

Yalabik, Zeynep Y., Patchara Popaitoon, Julie A. Chowne, and Bruce A. Rayton. 2013. Work engagement as a mediator between employee attitudes and outcomes. The International Journal of Human Resource Management 24: 2799-823. [CrossRef]

Yin, Robert K. 2017. Case study Research and Applications: Design and Methods. Thousand Oaks: Sage Publications.

(C) 2020 by the authors. Licensee MDPI, Basel, Switzerland. This article is an open access article distributed under the terms and conditions of the Creative Commons Attribution (CC BY) license (http://creativecommons.org/licenses/by/4.0/). 